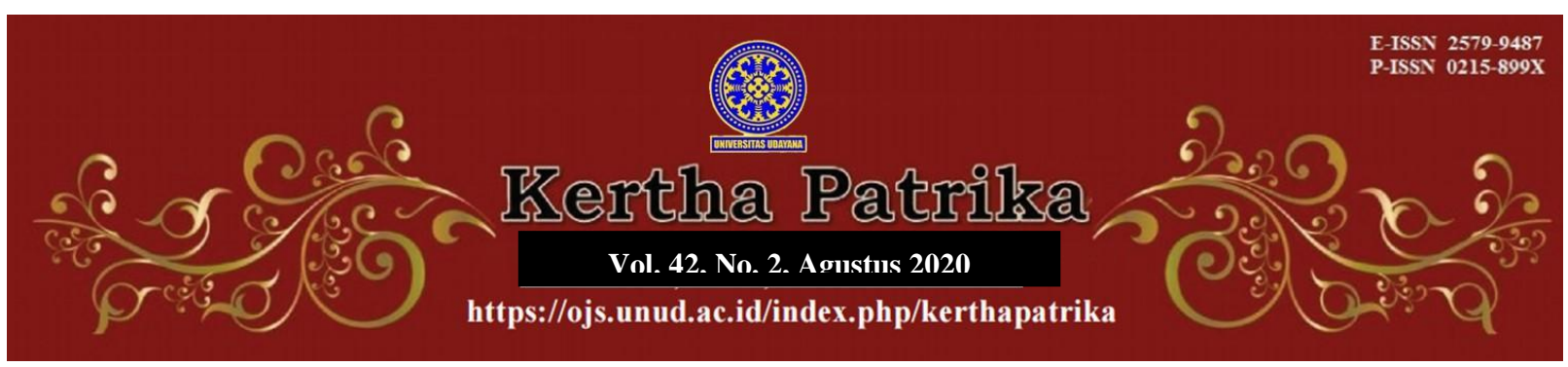

\title{
Moot Court as Learning Method for Bachelor of Law: Towards Progressive Legal Education
}

\section{Dewa Made Suartha1, I Dewa Agung Gede Mahardhika Martha²}

${ }^{1}$ Faculty of Law Udayana University, E-mail: dewa_suartha@unud.ac.id

2Faculty of Law Warmadewa University, E-mail: dewaagungdhika.martha@gmail.com

\begin{tabular}{l}
\hline Article Info \\
\hline Received: $27^{\text {th }}$ February 2020 \\
Accepted: $6^{\text {th }}$ August 2020 \\
Published : $31^{\text {th }}$ August 2020 \\
Keywords : \\
Progressive Law; Education; \\
Moot Court \\
Corresponding Author: \\
I Dewa Made Suartha, E-mail: \\
dewa_suartha@unud.ac.id \\
DOI: \\
10.24843/KP.2020.v42.i02.p01
\end{tabular}

\begin{abstract}
Moot court is onepractical learning method of procedural law learning that must be given to undergraduate law students. This learning method as a framework initiated by John Dewey as the achievement of progressive legal education, especially in criminal justice practices. The purpose of this learning method is to provide students with a deepening of criminal justice both based on theory and practice as well as provide opportunities for students to carry out the criminal trial practice by taking examples of criminal case decisions that have obtained permanent legal force. This paper specifically discovers, studies, analyzes and provides deepening related to criminal justice based on theory and practice for law students at the level of the Bachelor of Law program to obtain a progressive legal education The method used in this paper is empirical legal research method using primary data and secondary data based on a purposive sampling model with deep-interview concerning the practice of the moot court in law higher education. The results of this study indicate that students have gained a deepening of criminal procedural law, particularly in the implementation of criminal justice guided by supervisors and legal practitioners as tutors and instructors. This study also suggestedthat students have been able to practice criminal justice as true as actual criminal trials accompanied by supervisors and legal practitioners as their mentors in achieving progressive legal education.
\end{abstract}

\section{Introduction}

In general, the public's expectation of legal education is that graduation following the legal needs of the stakeholders. Students are motivated to involve in extra-curricular learning, including the Moot Court learning method that hasbeen conducted. Link and match gaps that are often complained of indicating the existence of problems that occur in reality so far that must be removed immediately. ${ }^{1}$ This is what lies behind the need for a learning method that combines the depth of theoretical study and empirical reality in the world of law today, especially for students of the Bachelor of Law program.

${ }^{1}$ Rustamaji, M. \& Gunawati, D. (2012). Aplikasi Metode Persidangan Semu pada Pembelajaran Hukum Pers bagi Penegak Hukum, Yustisia: Jurnal Hukum, 1(3), 67-79, DOI: https://doi.org/10.20961/yustisia.v1i3.10088, h. 73-74. 
The moot court which has traditionally been taught and carried out in the event of the competition, actually both, directly and indirectly, has great potential to become a method of progressive legal education. The moot court learning method which is expected to deliver students to become true learners throughout life, responds positively to every change that occurs in the community and is sensitive to the needs of the surrounding environment. For this reason, to create a progressive method of legal learning, an in-depth study is needed that describes all the learning activities that have existed so far, analyzes their strengths and weaknesses, ${ }^{2}$ designs progressive method, measures the potential for appropriateness of the application of the methods offered, ${ }^{3}$ and tests the learning methodin an atmosphere of empirical learning.

The hope of the integration of the academic world with the practice of reality, then the moot court learning method is what was initiated in the achievement of progressive legal education. A learning design that can produce outcomes in the form of enlightening learning methods (technological-humanist) and equip with efficient teaching materials. ${ }^{4}$ This progressive form of moot court learning is expected to ward off accusations that higher education only produces educated unemployment but is not competent with the labor market needed. Therefore, in this quasi-judicial learning method, new ideas will develop and follow the development of criminal justice practices.

Previous research that carried out limited to introducing thoughts to renew the process of legal education in Indonesia ${ }^{5}$ with a model that follows the times to realize the educational goals to produce students who are independent, able to solve legal problems, and become the pioneers of development through the field of law. ${ }^{6}$ This particular legal education integrates various legal learning practices and methods to improve legal skills in the form of litigation skills for law students through applied law studies, ${ }^{7}$ one of which is through a quasi-judicial model that incorporated into the Law Skills Practice course in the Law Science Bachelor program. ${ }^{8}$

This paper specifically discovers, studies, analyzes and provides deepening related to criminal justice based on theory and practice for law students at the level of the Bachelor of Law program to obtain a progressive legal education. In connection

2Susilo, I. (2017). Kedudukan Laboratorium Klinik dan Bantuan Hukum dalam Mengemban Tri Dharma Perguruan Tinggi (Studi Kasus pada Fakultas Hukum Uncen), Papua Law Journal, 1(2), 237-252, DOI: https://doi.org/10.31957/plj.v1i2.590, h. 240, 249-250.

${ }^{3}$ Bramantyo, R.Y. (2018). Strategi Mewujudkan Lulusan Fakultas Hukum Berkompetensi Spesifik (Pendidikan Hukum Indonesia dalam Tantangan Era Revolusi Industri 4.0), Jurnal Transparansi Hukum, 1(2), 140-151, DOI: http://dx.doi.org/10.30737/transparansi.v1i2.244, h. $147-148$

${ }^{4}$ Rahardjo, S. (2005). DelapanPuluhTahunPendidikanTinggiHukum Indonesia, Makalahpada Seminar NasionaldalamrangkaDies NatalisKe-48 FakultasHukumUniversitasDiponegoro, Semarang, 9 Januari, h. 12.

5Purbacaraka, P. \&Soekanto, S. (1983). PendidikanHukumdan Bahasa Hukum, JurnalHukum\& Pembangunan 13(3), 233-239, DOI: http:// dx.doi.org/10.21143/jhp.vol13.no3.965, h. 234.

${ }^{6}$ Wahjono, P. (1985). PendidikanHukum di Indonesia SuatuRetrospeksi, JurnalHukumE Pembangunan 15(5), 443-465, DOI: http://dx.doi.org/10.21143/ihp.vol15.no5.1161, h. 445.

${ }^{7}$ Harkrisnowo, H. (1996). Beberapa Catatan mengenai Matkul Pendidikan dan Latihan Kemahiran Hukum, Jurnal Hukum \& Pembangunan 26(5), 399-407, DOI: http://dx.doi.org/10.21143/jhp.vol26.no5.1072, h. 400.

${ }^{8}$ Maqdir Ismail, 2006, KurikulumPendidikanHukumdalamPersfektifKebutuhanPasar, Paper was presented on Seminar with theme "PengkajianKurikulum" at Faculty of LawUniversitas Islam Indonesia, 23 Desember, 1-17, h. 3-5, 9-10. 
with the intended context, this paper is also expected to provide the new sights of the opportunities to apply this method for the Bachelor of Law program. It has a purpose to carry out the practice of criminal case trials by taking examples of criminal case decisions that have obtained permanent legal force with the moot court method.

\section{Research Method}

The legal research methods are divided into two namely the normative legal research method and the empirical legal research method. ${ }^{9}$ Based on this classification, the method used in this study is an empirical legal research method. This study uses primary data obtained by the field study and secondary data obtained through the literature study. ${ }^{10}$ It analyzed using the statuteapproach and the conceptual approach. The primary data obtained using non-purposive sampling data with deep-interview concerning the practice of the moot court in law higher educational system and secondary data obtained by the snowball method. It analyzed through the descriptivequalitative and evaluative model.

\section{Results and Discussion}

\subsection{The Dynamics of Higher Education in Law: Legal Learning Model Based on Moot Court Model}

The 1945 Constitution of the Republic of Indonesia through Article 31 paragraphs (1) and (2) of the has expressly guaranteed the existence of human rights for every young generation, namely children, ${ }^{11}$ to receive education at the elementary, secondary and tertiary levels (from students to students). It has also been stimulated and regulated through several developments in legislation relating to the national education system. The national education system also specifically encourages higher education law to always adjust the development of curriculum and participatory learning systems involving the younger generation (children) as students, lecturers, and related employees who can support the printing of young people who are capable of developing skills and theoretical and practical knowledge. ${ }^{12}$ It was also marked by the pioneering arrangement of professional education with the Decree of the Minister of Education and Culture No. 17/D/0/1993 dated February 24, 1993, concerning Competency-based curriculum with applied methods that are nationally applicable for the Law Science Undergraduate Program and the Minister of Education Decree No.

9Sonata, D.L. (2014). Metode Penelitian Hukum Normatif dan Empiris: Karakteristik Khas dari Metode Meneliti Hukum.Fiat Justisia: Jurnal Ilmu Hukum, 8(1), 15-35, DOI: https://doi.org/10.25041/fiatjustisia.v8no1.283, h. 25-27.

${ }^{10}$ Choudhury, N. (2017). Revisiting Critical Legal Pluralism: Normative Contestations in the Afghan Courtroom. Asian Journal of Law and Society, 4(1), 229-255, DOI: 10.1017/als.2017.2, p. 231.

${ }^{11}$ Hermanto, B. \& Yusa, I G. (2018). Children Rights and the Age Limit: the Ruling of the Indonesian Constitutional Court. Kertha Patrika, 40(2), 61-70. DOI: 10.24843/KP.2018.v40.i02.p01, pp. 62-63.

${ }^{12}$ Disas, E.P. (2017). Analisis Kebijakan Pendidikan mengenai Pengembangan dan Peningkatan Profesi Guru, Jurnal Penelitian Pendidikan, 17(2), 158-166, h. 162. 
0325/U/1994. ${ }^{13}$ Article 23 of Law Number 20 the Year 2003 concerning the National Education System also stipulates that universities can carry out academic, professional or vocational programs. It can be said that the educational tradition that sees law is not only as a rule but also as a means of development. In the next stage, a legal learning method is introduced regarding training in professional skills, professional ethics, and professional responsibility. ${ }^{14}$

Therefore, an analysis of the law and regulations direction cannot be avoided from the labor market and the demand for graduates in the field of law. If it is true the assumption that legal education is practical education to meet market needs, then the market that most requires legal experts is those related to the judiciary, in which the law enforcement profession is struggling, be it judges, prosecutors, advocates, or nonlaw enforcers, such as legal to companies or government employees. ${ }^{15}$ This step must be done immediately under the consideration of law faculty directed by those laws and regulations to updating the legal education curriculum. The change is intended so that graduates do not just understand the theory but also master legal skills, so academic and professional legal education is not united in one curriculum. The integration of academic and professional legal education is not realistic. ${ }^{16}$ The time allocated for students to have theoretical and practical knowledge is too short. For this reason, the Faculty of Law is expected to have a legal laboratory that can be used as a medium for law school students in developing good practice skills in the sense of avoiding the "dirty" practice commonly called the judicial mafia. In general, the tasks of the Law Laboratory are: (a) to conduct skills education (specifically and separately), and (b) to foster (the lecturers) using an applied approach through the provision of material for lecturers, as well as encouraging lecturers to use material from case studies.

The next step that must be built is an optimistic attitude, as once stated by ErmanRajagukguk, in his speech when confirmed as Professor of Law, concluded: "... legal education produces law graduates who have skills in legal practice that contain international elements; on the other hand equip them with the ability to deal with various problems faced by society, including providing legal assistance to those most affected by globalization ".17

Thus what is appropriate to immediately think about and do now is to make legal education in one unit with legal development, so that the direction of legal education is to educate students so that they can contribute to the development and law enforcement. The structure and content of legal education from the past until now

${ }^{13}$ Reksodiputro,

M.

LaboratoriumHukumsebagaiWadahPendidikandanPenulisanHukum,

Pembangunan 24(6), 485-490, DOI: http://dx.doi.org/10.21143/jhp.vol24.no6.1055, h. 486.

${ }^{14}$ Anwar, K. (2011). Pendidikan Hukum di Era Transisi dalam Negara Demokrasi menuju Indonesia Baru, Masalah-masalah Hukum, 40(2), 236-245, DOI: 10.14710/mmh.40.2.2011.236-245, h. 240 .

${ }^{15}$ Somantri, S. (2019). Jaminan Perlindungan Hukum sebagai Prinsip Profesionalitas Dosen dalam Pengembangan Ilmu Pengetahuan dan Teknologi (IPTEK), Jurnal Hukum Positum, 4(2), 95-119, DOI:http://dx.doi.org/10.35706/positum.v4i2.3185, h. 99-101.

16Juwana, H. (2005). Reformasi Pendidikan Hukum di Indonesia, Jurnal Hukum dan Pembangunan, 35(1), DOI: http://dx.doi.org/10.21143/ihp.vol35.no1.1458, 1-26, h. 23-24.

${ }^{17 R a j a g u k g u k, ~ E . ~(1997) . ~ P e r a n a n H u k u m d a l a m ~ P e m b a n g u n a n ~ p a d a ~ E r a ~ G l o b a l i s a s i: ~}$ ImplikasinyabagiPendidikanHukum di Indonesia, PidatoPengukuhanUpacaraPenerimaanJabatan Guru BesardalamBidangHukum, FakultasHukumUniversitas Indonesia, h. 27. 
is very much emphasized on the systematic and content of the rule of law. ${ }^{18}$ As a result, legal education and its results are less functional in developing and filling precisely the other components of the legal subsystem, so that legal education will not have any contribution to the development of law and law enforcement. Legal education that can give birth to students to carry out legal development and be able to become law enforcers can only be done by involving students in research activities and practical activities. ${ }^{19}$ The moot court learning method as an embodiment of criminal justice practice, which includes: analyzing cases, examining case files, filing, and conducting examinations according to the way students and court practice, is a start that should continue to be developed. The moot court learning method has been implemented under the subject of Law Skills Practice course. In the next stage, apprenticeship activities at the Advocate, Attorney's Office and in the Court, have also been carried out by various faculties of law in Indonesia including by the Faculty of Law of Udayana University so far will further enrich students' insights and skills when confronted with the legal realities in their enforcement and how the law applies in an empirical world that is full of twists and turns barriers to the alienation of factors outside the law.

In addition to apprenticeship activities for the benefit of students toreviewthe legal education curriculum on an ongoing basis and adapted to the real needs. ${ }^{20}$ This assessment step is expected, "will overcome the rigidity and insensitivity to the changing needs of society which up to now are the weaknesses of many of our universities". ${ }^{21}$ Continuous discussion and review of the legal education curriculum is the time not only conducted by the teaching staff but also involves researchers and legal practitioners, both as alumni or as experts.

The curriculum issue is not only a matter of what should be taught but also concerns what topics are appropriate and needed by the community in the future when students return to the community. Things like this are referred to by Conant as "clinical professors" because the professor is a practitioner who practices a variety of theories every day into practice appropriately. Well-planned clinical education not only teaches technical skills but must also expose students to the conditions that will be encountered in society in the future and must also add a habit or attitude to a problem that can be called a problem-solving attitude..$^{22}$

The legal education curriculum should be thought of as what is done by a professor who practices medical theory into daily doctor practice. This model-based curriculum encourages students to think and solve problem deadlock independently

\footnotetext{
${ }^{18}$ Hastuti, T.P. \& Soehartono, S. (2018). Kebijakan Pendidikan di tinjau dari Segi Hukum Kebijakan Publik, Jurisprudence, 8(1), 34-41, DOI: https://doi.org/10.23917/jurisprudence.y8i1.6293, h. 36-37.

${ }^{19}$ Fidiyani, R. (2010). Pergeseran Paradigma dalam Pendidikan Tinggi Hukum (dari Kurikulum Inti dan Institusional ke Kurikulum Berbasis Kompetensi), Jurnal Dinamika Hukum, 10(3), 243256, DOI: http://dx.doi.org/10.2884/1.jdh.2010.10.3.95, h. 253-254.

${ }^{20}$ Zahir, B. (2010). PendidikanTinggi: HubungandenganMasyarakatdanKeadaanSekarang, JurnalPrisma LP3ES, VII(2), 22-31, h. 28.

${ }^{21}$ Toisuta, $\quad$ W. (2011). KurikulumPerguruanTinggi: PerimbanganantaraBebanBelajardanMengajar, JurnalPrisma LP3ES, VIII(1), 24-41, h. 37.

${ }^{22}$ Mulyani, L. (2010). Pendekatan Sosial dalam Penelitian Hukum, Jurnal Masyarakat \& Budaya, 12(3), 35-56, DOI: http://dx.doi.org/10.14203/jmb.v12i3.150, h. 48-49.
} 
because they have the opportunity to gain hands-on experience in practice. ${ }^{23} \mathrm{~W}$ ith this conception, it can be interpreted that this kind of curriculum is expected to give birth to a Law Bachelor who can carry out legal development and is also able to enforce law because students get strong and effective evidence and receive practical lessons as lawyers because they deal directly with clients, prosecutors / attorney general and judges during the trial, besides that students also get the opportunity to contribute in law enforcement. It is in this context that is the basis of the moot court learning method, to provide a correlative and continuous empirical experience in applying the theorization of legal science in its enforcement, although it is still limited to the case position approach introduced from the actual story in the community.

\section{2.b. Implementation of Moot Court Trial Practices}

The implementation of moot court learning methods can be focused on a learning design model that presents learning plans and learning procedures and their implementation. ${ }^{24}$ During this time the obstacle turns out to lie in the design of oneway learning without trying to open up opportunities for students to gain the widest experience in the learning process. Inventory of problems in the implementation of moot court learning so far which includes the determination and selection of support staff is constrained by teaching staff or supervisors who feel they can teach anything without focusing and updating information in their field of science. ${ }^{25}$ The determination of management control is doctrinal normative following statutory provisions, in this case, the Criminal Procedure Code but this becomes problematic when there are updates such as evidence and the value/strength of electronic evidence, ${ }^{26}$ for example. The identification of the student population can be helped by the creation of small classes, an atmosphere of competitive rivalry and focus as applied by the Faculty of Law, Udayana University for the development of soft skills. The collection of learning materials is known to be strongly supported by the sophistication of information technology through the internet that facilitates data updates and legal developments needed in a case study of moot court learning. ${ }^{27}$

The 'context' analysis places students in a real court situation by playing role play in a series of moot court learning methods. By opening an effective communication faucet and providing flexibility for students as moot court learning centers, progress in learning is obtained that is so rapid by getting closer to the world of education with the practice of real law. This is indicated by the provision of skills in dissecting position cases, making legal memoranda, examining students according to

\footnotetext{
${ }^{23}$ Sahlan, S., Suhadi, S. \& Arifin, S. (2015). Kebutuhan Program Continuing Legal Education bagi Mahasiswa Fakultas Hukum, Pandecta, 10(2), doi: http://dx.doi.org/10.15294/pandecta.v10i2., 234-247, h. 240.

${ }^{24}$ Suparman, M.A. (2015). DesainInstruksionalPekertiMengajar di PerguruanTinggi, DirjenDiktiPusatAntarUniversitasuntukPeningkatandanPengembanganAktivitasInstruksional, Jakarta, h. 13.

${ }^{25}$ Murwadji, T. (2017). Integrasi Ilmu Mutu kedalam Audit Mutu Hukum di Indonesia, Jurnal Hukum Positum, 1(2), 150-168, DOI: http://dx.doi.org/10.35706/positum.v1i2.845, h. 153-156.

${ }^{26}$ Rustamaji, M. \&Gunawati, D. (2011),Mootcourt 'Membedah' Peradilan Pidana dalam Kelas Pendidikan HukumProgresif, Mefi Caraka, Surakarta, h. 59.

${ }^{27}$ Febriany, T.A. \& Kurniawan, H.Y. (2019). Efektivitas Penggunaan Video sebagai Media Pembelajaran pada Perguruan Tinggi (Studi Kasus pada Mata Kuliah Hukum Acara Perdata), Res Judicata, 2(1), 243-258, DOI: http://dx.doi.org/10.29406/ri.v2i1.1485, h. 246-248.
} 
comparison cases, mastery in compiling files/BAP (Examination Event) by Police investigators, compiling files/BAP (Minutes of Examination) by public prosecutors and files/BAP (Minutes of Examination) of the court hearing so that the peak demonstrates the role of each law enforcer in a moot court simulation. These various skills will be increasingly developed for the freedom given to access information sources, both from lecturers and their academic literature, as well as partner lecturers (guest lecturers) from practitioners with flying hours of law enforcement experience.

The implementation of moot court learning methods from the UMCC (Udayana Moot Court Community) Faculty of Law, Udayana University and various universities that are members of the ALSA (Asian Law Students Association) and SCIL (Student Community of International Law) being developed this method for several legal equipping and legal competition to showingthe high competence in the development of moot courts, both in filing and moot court appearance.

The completeness of the dossier and the use of the latest legal arguments are prominent features in a filing. While the basic legal debate and technology optimization become legal breakthroughs that are carried by moot court teams in presenting a pseudo court simulation. The submission of experts who presented evidence of hooked evidence, DNA testing (Genetic Fingerprinting), dismantling call data records of telephone calls, and recording of conversations through interception (wiretapping) are a few examples that are commonly displayed for moot court teams when competing in a competition. But at the same time, many moot court teams from several regions are far from the criteria of meeting the provisions of the Criminal Procedure Code, both in the preparation of files and in proceedings in criminal justice. This is certainly very worrying for the future of law enforcement in the future. The disparity that is so lame, one of which is caused by not mastering the stages of the proceedings and preparation of documents, which are often not met within the limited time limit of moot court competition (filing of more or less two months and the trial process is more or less within the range of 80 minutes ).

Based on observations and observations of the results of the moot court learning which results in conditions of self-development (inequality) and inequality, it is found that the root causes of the problem are the one-way learning patterns that are still maintained by the instructors (moot court advisers). The relatively low learning independence is also an important cause that is no less significant for a moot court team so that it does not have sufficient competence in a race.

Learning from a comparative analysis of the implementation of moot court and reading of John Dewey's literacy of thought (progressive education in 1924) and SatjiptoRahardjo (Progressive Law of 2005), ${ }^{28}$ an embryo of progressive moot court learning methods manifests in the flow of trials which is coherent with technologicalhumanist nuances. John Dewey's thinking with his progressive learning conception is placed as a learning context that presents a wealth of experience for students with the freedom to interact with learning media, learning resources and the presence of learning methods. Whereas at the same time the content of legal science was developed with SatjiptoRahardjo's thoughts on law for humans, not vice versa. This combination will further produce the concept of Progressive Legal Education.

28Dewey, J.(2008). Pengalaman dan Pendidikan (Experience and Education), terjemahan,Kepel Press, Yogyakarta, h. 10, 21. 
P-ISSN: 0215-899X, E-ISSN: 2579-9487 


\section{Conclusions} as follows:

Based on the results of the research and discussion above, it can be concluded

1. The national law and policy on higher education have inspired the tradition of education which sees law not only as a rule but also increases leads to bringing legal education closer to the actual practice of law. Moot court is an example of how law students are introduced with practices of legal professionals as an implementation of procedural law that they learn in the class.

2. The practice of criminal justice with the skill of dissecting position cases, making legal memorandums, examining comparative cases, mastering the BAP file and trial files, demonstrating the role-play in a moot court simulation competition so far have shown significant progress.

Based on the results of the research, discussion, and conclusions above, it can be suggested to researchers who are interested in a similar field and the moot court teachers/advisors that:

1. Further research should be carried out to identify the dominant factors that influence a moot court learning method and its analysis, as a form of followup to comparative studies.

2. Study of certain criteria should be carried out in the moot court design analysis which includes criteria for identifying behavioral goals and measuring performance, determining criteria for adjusting for individual differences, all of which lead to the creation of moot court learning methods with the practice of law as a real law enforcement officer in social life.

\section{Bibliography}

\section{Books}

Dewey, J.(2008). Pengalaman dan Pendidikan (Experience and Education), terjemahan,Kepel Press, Yogyakarta.

Rustamaji, M. \& Gunawati, D. (2011),Mootcourt 'Membedah' Peradilan Pidana dalam Kelas Pendidikan HukumProgresif, Mefi Caraka, Surakarta.

Suparman, M.A. (2015). DesainInstruksionalPekertiMengajar di PerguruanTinggi, DirjenDiktiPusatAntarUniversitasuntukPeningkatandanPengembanganAktivit asInstruksional, Jakarta.

\section{Journal and Related Publication}

Anwar, K. (2011). Pendidikan Hukum di Era Transisi dalam Negara Demokrasi menuju Indonesia Baru, Masalah-masalah Hukum, 40(2), 236-245, DOI: 10.14710/mmh.40.2.2011.236-245.

Bramantyo, R.Y. (2018). Strategi Mewujudkan Lulusan Fakultas Hukum Berkompetensi Spesifik (Pendidikan Hukum Indonesia dalam Tantangan Era Revolusi Industri 4.0), Jurnal Transparansi Hukum, 1(2), 140-151, DOI: http://dx.doi.org/10.30737/transparansi.v1i2.244.

Choudhury, N. (2017). Revisiting Critical Legal Pluralism: Normative Contestations in the Afghan Courtroom. Asian Journal of Law and Society, 4(1), 229-255, DOI: 10.1017/als.2017.2. 
Disas, E.P. (2017). Analisis Kebijakan Pendidikan mengenai Pengembangan dan Peningkatan Profesi Guru, Jurnal Penelitian Pendidikan, 17(2), 158-166.

Febriany, T.A. \& Kurniawan, H.Y. (2019). Efektivitas Penggunaan Video sebagai Media Pembelajaran pada Perguruan Tinggi (Studi Kasus pada Mata Kuliah Hukum Acara Perdata), Res Judicata, 2(1), 243-258, DOI: http://dx.doi.org/10.29406/rj.v2i1.1485.

Fidiyani, R. (2010). Pergeseran Paradigma dalam Pendidikan Tinggi Hukum (dari Kurikulum Inti dan Institusional ke Kurikulum Berbasis Kompetensi), Jurnal Dinamika Hukum, 10(3), 243-256, DOI: http://dx.doi.org/10.2884/1.jdh.2010.10.3.95.

Harkrisnowo, H. (1996). Beberapa Catatan mengenai Matkul Pendidikan dan Latihan Kemahiran Hukum, Jurnal Hukum \& Pembangunan 26(5), 399-407, DOI: http://dx.doi.org/10.21143/jhp.vol26.no5.1072.

Hastuti, T.P. \& Soehartono, S. (2018). Kebijakan Pendidikan di tinjau dari Segi Hukum Kebijakan Publik, Jurisprudence, 8(1), 34-41, DOI: https://doi.org/10.23917/jurisprudence.y8i1.6293.

Hermanto, B. \& Yusa, I G. (2018). Children Rights and the Age Limit: the Ruling of the Indonesian Constitutional Court. Kertha Patrika, 40(2), 61-70. DOI: 10.24843/KP.2018.v40.i02.p01, pp. 62-63.

Ismail, M. (2006), Kurikulum Pendidikan Hukum dalam Persfektif Kebutuhan Pasar, Paper was presented on Seminar with theme "Pengkajian Kurikulum" at Faculty of Law Universitas Islam Indonesia, 23 Desember, 1-17.

Juwana, H. (2005). Reformasi Pendidikan Hukum di Indonesia, Jurnal Hukum dan Pembangunan, 35(1), DOI: http:/ / dx.doi.org/10.21143/jhp.vol35.no1.1458, 1-26.

Mulyani, L. (2010). Pendekatan Sosial dalam Penelitian Hukum, Jurnal Masyarakat $\mathcal{E}$ Budaya, 12(3), 35-56, DOI: http:// dx.doi.org/10.14203/jmb.v12i3.150.

Murwadji, T. (2017). Integrasi Ilmu Mutu kedalam Audit Mutu Hukum di Indonesia, Jurnal Hukum Positum, 1(2), 150-168, DOI: http://dx.doi.org/10.35706/positum.v1i2.845.

Purbacaraka, P. \& Soekanto, S. (1983). Pendidikan Hukum dan Bahasa Hukum, Jurnal Hukum $\mathcal{E}$ Pembangunan 13(3), 233-239, DOI: http://dx.doi.org/10.21143/jhp.vol13.no3.965.

Rahardjo, S. (2005). DelapanPuluhTahunPendidikanTinggiHukum Indonesia, Makalahpada Seminar NasionaldalamrangkaDies NatalisKe-48 FakultasHukumUniversitasDiponegoro, Semarang, 9 Januari.

Rajagukguk, E. (1997). PerananHukumdalam Pembangunan pada Era Globalisasi: ImplikasinyabagiPendidikanHukum di Indonesia, PidatoPengukuhanUpacaraPenerimaanJabatan Guru BesardalamBidangHukum, FakultasHukumUniversitas Indonesia.

Reksodiputro, M. (1994). Laboratorium Hukum sebagai Wadah Pendidikan dan Penulisan Hukum, Jurnal Hukum \& Pembangunan 24(6), 485-490, DOI: http://dx.doi.org/10.21143/jhp.vol24.no6.1055.

Rustamaji, M. \& Gunawati, D. (2012). Aplikasi Metode Persidangan Semu pada Pembelajaran Hukum Pers bagi Penegak Hukum, Yustisia: Jurnal Hukum, 1(3), 67-79, doi: https://doi.org/10.20961/yustisia.v1i3.10088.

Sahlan, S., Suhadi, S. \& Arifin, S. (2015). Kebutuhan Program Continuing Legal Education bagi Mahasiswa Fakultas Hukum, Pandecta, 10(2), DOI: http://dx.doi.org/10.15294/pandecta.v10i2., 234-247. 
Soedjatmoko, S. (2013). BeberapaFikirantentangPerguruanTinggi, JurnalPrisma LP3ES, XI(1), 21-35.

Somantri, S. (2019). Jaminan Perlindungan Hukum sebagai Prinsip Profesionalitas Dosen dalam Pengembangan Ilmu Pengetahuan dan Teknologi (IPTEK), Jurnal Hukum Positum, 4(2), 95-119, DOI:http://dx.doi.org/10.35706/positum.v4i2.3185.

Sonata, D.L. (2014). Metode Penelitian Hukum Normatif dan Empiris: Karakteristik Khas dari Metode Meneliti Hukum.Fiat Justisia: Jurnal Ilmu Hukum, 8(1), 15-35, doi: https:/ / doi.org/10.25041/fiatjustisia.v8no1.283.

Susilo, I. (2017). Kedudukan Laboratorium Klinik dan Bantuan Hukum dalam Mengemban Tri Dharma Perguruan Tinggi (Studi Kasus pada Fakultas Hukum Uncen), Papua Law Journal, 1(2), 237-252, DOI: https://doi.org/10.31957/plj.v1i2.590.

Toisuta, W. (2011). KurikulumPerguruanTinggi: PerimbanganantaraBebanBelajardanMengajar, JurnalPrisma LP3ES, VIII(1), 2441.

Wahjono, P. (1985). Pendidikan Hukum di Indonesia Suatu Retrospeksi, Jurnal Hukum $\mathcal{E}$ Pembangunan 15(5), 443-465, DOI: http://dx.doi.org/10.21143/jhp.vol15.no5.1161.

Zahir, B. (2010).

PendidikanTinggi: HubungandenganMasyarakatdanKeadaanSekarang, JurnalPrisma LP3ES, VII(2), 22-31.

\section{Law and Regulations}

The 1945 Constitution of the Republic of Indonesia.

Law Number 20 of 2003 concerning the National Education System.

Minister of Education and Culture Decree Number 17/D/0/1993 junctoMinister of Education Decree Number 0325/U/1994 concerning Curricula based on applied methods that apply nationally for the Bachelor of Laws Undergraduate Program. 